JPH: Jurnal Pembaharuan Hukum

Volume 8, Number 1, April 2021

\title{
NOTARY RESPONSIBILITY FOR ELECTRONIC STORAGE OF NOTARY PROTOCOLS
}

\author{
Ngadino \\ Sultan Agung Islamic University \\ ngadinod238@gmail.com
}

\begin{abstract}
The notary protocol is a state archive that must be kept and guarded by a notary public. Due to security concerns, maintenance costs and the size of space required further electronic storage of notary protocols can be carried out. This legal research uses a normative juridical approach as a result of the absence of norms. The technique of using legal materials used is the card system technique. The results show that the notary protocol that is stored electronically is important to do considering the duties of a notary as a public official who has the task of searching for the public in the field of civil cases so that the state must make rules regarding the storage of notary electronic protocols in its arrangement with Cyber Notary. The mechanism is to use the transfer media in digital form or scanning. The strength of notary protocol evidence stored in the field of civil law only functions as a backup, not as an electronic one which has binding power because it does not meet the requirements for document authenticity as regulated in Article 1 paragraph. 7 of the Amendments to the Law on Notaries and Article 1868 of the Civil Code and in the field of criminal procedural law, namely that it can be evidence to show evidence that shows other evidence.
\end{abstract}

Keywords: electronic storage, notary protocol, cyber notary

\section{A. INTRODUCTION}

Notary public is a public official appointed by the government to assist the general public in terms of making existing agreements or arising in the community. The necessity of these written agreements made before a Notary is to ensure legal certainty and to fulfill a strong law of proof for the parties to the agreement. The need for a written proof requires the importance of Notary institution. ${ }^{1}$

Notary is called a noble official because the notary profession is very closely related to humanity. A Deed made by a Notary can be a legal proof of the status of a person's property, rights and duties. The mistake of a deed made by a Notary may result in the deprivation of a person's right to an obligation. ${ }^{2}$

1 R.Soegondo Notodisoeryo, Hukum Notariat di Indonesia, PT.Raja Grafindo, Fouth Publishing, Jakarta, 2012, page.4

2 Abdul Muin, Notary's Responsibility To The Truth of Data In The Making of Islamic Banking Contract in Indonesia, Jurnal Pembaharuan Hukum, Volume V No. 1 April-Agustus 2018, page.47-54 
Not only do notaries have authority but also office administration obligations like a company. Administration of a notary office can be defined as activities that are written in nature (administrative activities), such as writing a list of deeds, a list of letters under legalized hands, a list of underhanded letters, an alphabetical Klapper list, a protest list book; a wills register, and a limited liability company register book. The notary's administrative activities are inseparable from the notary's managerial expertise to carry out filing procedures. The notary office filing is also a part of the notary's administrative activities. The procedure for keeping the original or original deed and its documents is also the responsibility of the notary in order to maintain and maintain state archives properly and seriously. ${ }^{3}$

The provisions of Article 65 of Law Number 30 of 2004 concerning the Position of Notary Public as amended by Law Number 2 of 2014 regulate and determine the responsibilities of a notary, especially on each deed he makes even though the notary protocol has been submitted or transferred to the notary protocol depositor. The responsibility of a notary during his tenure is also related to the storage of all protocols he has.

In Article 1 number 13 of the Law on Notary Publication, the notary protocol defines a notary protocol as a collection of documents which constitute a state archive that must be kept and maintained by a notary by the provisions of laws and regulations. Notary protocol rules in Article 63 paragraph (5) Notary Notary Office Law Amendments regarding the submission of notary protocols to substitute notaries whose time of submission is 25 years old or more to the Regional Supervisory Council (MPD) cannot be applied because the MPD is unable to store the large number of available notary protocols. has been over 25 years old in the Regional Supervisory Council office. This causes the notary protocol to be kept at the notary office concerned.

Due to the importance of the position of the authentic deed made by the notary public, so keeping the minimum deed as part of the notary protocol is also important. The substitute notary is also obliged to keep the protocol that has been passed on to him by the notary who has passed away. You can imagine how much space is needed to store the notary protocol, as well as the risk in case of fire, being bitten by rats or other insects, and floods. Therefore, to anticipate the impact of the storage and maintenance process which is constrained on the place and costs of the treatment, the solution for the storage of the notary protocol is through the application of information technology or electronically.

The rapid development of information technology has influenced the practice of notary in Indonesia. This influence can be seen in the explanation of Article 15 paragraph (3) of the Amendment of the Law on Notary Position with the term cyber notary. However, the Law on Notary Position does not yet regulate the development of information technology-

3 Mohamat Riza Kuswanto, Hari Purwadi, Urgensi Penyimpanan Protokol Notaris Dalam Bentuk Elektronik dan Kepastian Hukumnya di Indonesia, Jurnal Repertorium, Volume IV No. 2 JuliDesember 2017, page.62-69 
based notary protocol storage. The provisions of Article 16 paragraph (1) letter $b$ of the Law on the Position of Notary Public and its explanation only stipulate the obligations of a notary in carrying out his office, namely to make deeds in the form of a deed and keep it as part of the notary protocol in its original form to maintain the authenticity of a deed so that if any falsification or misuse of grosse, copies, or quotations can be readily discovered by matching the originals.

The purpose of writing in this study is to determine and analyze the urgency of notary protocols stored electronically to improve services by utilizing information technology in terms of cyber notaries and to develop legal thinking about opportunities for improving services by notaries through the use of information technology, this is related to protocol storage. notary electronically in anticipation of the conventional storage constraints that have been carried out about cyber notaries.

\section{B. RESEARCH METHODS}

Research method uses a normative juridical approach, secondary data types, data collection methods that are carried out by literature, and the internet. While the data analysis method was analyzed descriptively qualitatively. Research carried out on the actual situation that is happening in the community with the intention of knowing and finding the facts and data needed, after the required data has been collected, then identifies the problem which in turn leads to problem solving. ${ }^{4}$ This research will provide an overview of a particular symptom or problem. This study seeks to explain the main issues under study in full, namely the implementation of credit and execution of Mortgage Rights in accordance with the findings in the field. ${ }^{5}$

\section{RESULT AND DISCUSSION}

\section{Electronic Notary Protocol Storage Arrangement}

The process of law enforcement, legal application, or law enforcement is the most important part of realizing the rule of law. Without a law enforcement process, order and tranquility will never be realized, so legal regulations are only words that have no meaning in life. ${ }^{6}$ According to Soerjono Soekanto, law enforcement is an activity to harmonize the relationship of values that are described in solid principles / views and embody attitudes as a series of final-stage value descriptions to create social engineering and maintain peace in social life. ${ }^{7}$ In line with that, Satjipto Rahardjo also emphasized that law enforcement is a process to turn legal desires into reality. What is meant by legal desires

4 Bambang Waluyo, Penelitian Hukum Dalam Praktek, Sinar Grafika, Jakarta, 2002, page.16

5 Burhan Ashsofa, Metode Penelitian Hukum, Rineka Cipta, Jakarta, 2013, page.13

6 Titik Triwulan and Ismu Gunadi Widodo, State Administrative Law and Indonesian State Administrative Court Procedure, Kencana, Jakarta, 2011, page. 339.

7 Alimuddin Siregar, Pornography Law Regulations, Scopindo Media Pustaka, Surabaya, 2019, page.95. 
are the thoughts of a legislative body formulated in statutory regulations. ${ }^{8}$

a. Legal Basics of Notary Protocol Electronic Storage by Notary

According to Article 15 paragraph (1), Article 16 paragraph (1) letter b, Article 58, Article 59, and Article 63 Notary Office Law that notaries are responsible for keeping notaries' deeds and protocols during their tenure and will be continued by the next notary who replaces them.

The work of notaries is still very much dependent on paper as a medium, so it takes a large space and quite expensive maintenance to secure these files. In connection with this problem, the application of information technology products can be a solution option for solving these storage problems. Article 68 paragraph (1) of the Archive Law has stipulated that "Creators of archives and/or archival institutions can create archives in various forms and/or transfer media including electronic media and/or other media", but the notary has yet to implement it. In the Amended Notary Office Law, there is no regulation regarding the electronic storage of notary protocols. Only the elucidation of Article 15 paragraph (3) states the possibility of a notary to certify transactions conducted electronically (cyber notary). The government, through the Ministry of Law and Human Rights, began to provide legal services online with the issuance of Regulation of the Minister of Law and Human Rights Number 4, 5, 6 of 2014. No rules are governing electronic storage of notary protocols in Notary Notary Office creating a norm vacuum. Based on Plato's view that a good country is a country that is based on good regulations, according to the author regarding the notary protocol is a state archive that must be kept and kept secret by a notary who in this case carries out some of the state's duties, so the state should make strict and clear rules governing the electronic storage of notary protocols related to the cyber notary. Good statutory rules are regulations that provide legal certainty to create a safe and peaceful atmosphere in society. Regarding the theory put forward by Van Apeldoorn regarding legal certainty which means that:

1) Legal certainty is something that can be determined from the law, related to concrete matters.

2) Legal certainty is legal security. One of the ways to achieve legal certainty is if there are clear and consistent rules. The laws and regulations referred to in this discussion are the implementing regulations of the Notary Office Law relating to the electronic storage of notary protocols.

b. Electronic Notary Protocol Storage Function

The notary's obligation to make deeds in the original form of deeds is based on the provisions of Article 16 paragraph (1) letter $b$ of the Amendment notary office law along with its explanation only

8 Y.Sri Pudyatmoko, Licensing: Problems and Efforts to Improve, Grasindo, Jakarta, 2009, page. 111. 
stipulate the notary's obligations in carrying out his / her office, namely to make deeds in the form of a minimum deed and keep them as part of the notary protocol in its original form to maintain the authenticity of a deed so that if any falsification or misuse of grosse, copies, or quotations can be found out easily by matching them with originals. $^{9}$

Technology offers a more practical, efficient, inexpensive, and safe way of storing notary protocols, namely through electronic storage. The enactment of Law Number 8 of 1997 concerning Company Documents (hereinafter referred to as the Company Documents Law), is the starting point for the transfer of data in the form of letters or writing on paper into electronic media. As stated in the consideration of the formation of this law, in the section considering the letter $f$ that technological advances have enabled records and documents made on paper to be transferred to electronic media. Based on the preamble of letter e of the Company Documents Law, media transfer is an option so that a company in storing documents does not incur economic and administrative burdens. The function and purpose of storing notary's protocol electronically can be assessed from two aspects, namely economic aspects and legal aspects. Economically, notary protocol storage aims to be more practical, efficient, cheap, and safe. Meanwhile, in terms of legal aspects, notary protocol storage electronically can help and facilitate legal processes, especially legal evidence relating to electronic evidence.

c. Notary Protocol Electronic Storage Mechanism

The procedure for keeping the original or original deed and its documents is also the responsibility of the notary in the framework of maintaining and maintaining state archives properly and seriously. The connection in the world of notaries is to minimize the use of paper (paperless) and the possibility of loss of reporting archives, even further that minuta and copies of deeds can also be transferred to scanning files as material for supervision to notaries in carrying out their activities. The regulations regarding the minimum deeds and notary protocols contained in the Notary Office Law are limited to making, storing and submitting notary protocols, as contained in Article 58 to Article 65.

Even though the Notary Office Law does not regulate and do not require notaries to keep their documents in electronic form, this can be done to reduce all risks and the worst possible case for the documents they store. Media that can be considered for use as data or information storage by technological developments, namely: ${ }^{13}$

1) Magnetic tape is a storage medium made of magnetic material superimposed on a thin plastic, such as tape on a cassette tape.

2) Magnetic disk is a disk-shaped storage medium.

9 Cut Era Fitiyeni, Tanggung Jawab Notaris Terhadap Penyimpanan Minuta Akta Sebagai Bagian Dari Protokol Notaris, Kanun Jurnal IImu Hukum No. 58, th XIV Desember 2012, page. 392 
3) An optical disc is a disc that can hold data up to hundreds or even thousands of times compared to a floppy disk.

4) USB Flash Disk is a data storage device shaped like a pen, how to use it by connecting it to a USB port.

5) Memory card is a type of storage such as thin plastic commonly used in PDAs, digital cameras, cell phones, and handycames.

Electronic notary protocol storage is carried out as a precautionary step in the process of storing and maintaining the notary protocol from the risk of damage and even loss of the notary protocol. The laws and regulations, including the NOTARY OFFICE LAW, do not regulate the electronic notary protocol storage mechanism in anticipation of damage, loss or destruction of the notary protocol in which there is a minimum deed which is authentic proof of the letter The electronic notary protocol storage mechanism can be used by the process of transferring media from printed documents, audio, video to digital form or what is called scanning. The method of storing the minimum deed like that can be done by the notary as a form of security. The system for digitizing documents starts from taking the archive for checking, then scanning it. The scanning results are stored in the database server and automatically the output of the document digitization scan data is available. The results stored on the database server are stored in the form of a Flashdisk or stored on a memory card with a capacity that is adjusted to the amount of data. Then to maintain security, the database server and flashdisk are stored in a fire-proof deposit box or safe for later storage by a notary or the storage can be handed over to MPD. With the electronic document generated through this process, it can be opened when needed and a copy made for further use to represent the damaged or lost notary protocol.

\section{Strength of Evidence of the Notary Protocol that is Stored Electronically}

The status of the authentic deed made by the notary, so that the deposit of the deed as part of the notary protocol is also important. The substitute notary is also obliged to keep the protocol that has been passed on to him by the notary who has passed away. You can imagine how much space is needed to store the notary protocol, as well as the risk in case of fire, being bitten by rats or other insects, and floods. Therefore, to anticipate the impact of the storage and maintenance process which is constrained by the location and maintenance costs, the solution for the storage of the notary protocol is through the application of information technology or electronically. Based on Article 1 number 3 Law Number 11 Year 2008 concerning Electronic Information and Transactions. Information is a technique for collecting, preparing, storing, processing, announcing, analyzing, and / or disseminating 
information. The rapid development of information technology has influenced the practice of notary in Indonesia. ${ }^{10}$

a. The Legal Strength of Notary Protocol that is Stored Electronically in Evidence in the Field of Civil Procedural Law

In Indonesia, the electronic proof system in the Transaction and Electronic Information Law is still exempted because letters and documents must be made in the form of notarial deeds or deeds drawn up by deed-making officials, also taking into account the provisions of Article 1868 of the Civil Code. In Article 1866 of the Civil Code, evidence consists of: 1) written evidence, 2) witness evidence, 3) suspicion, 4) confession, and 5) oath. Notary protocols that are stored electronically such as Print Out, scanning microfilm, hard disks or flash drives and other storage media, namely non-paper information storage devices that have a level of security that can guarantee the authenticity of documents transferred to them, as well as electronic documents that have been regulated as tools evidence recognized at court in the form of material law through the Company Documents Act and the transaction and electronic information law.

Apart from the transfer of documents in electronic form, the original manuscripts still have the power of authentic proof as long as they are made by the competent authority and the original manuscripts must be kept. And referring to Article 1888 of the Civil Code that the power of proof of written evidence is the original deed. In the process of proof in court if only electronic documents can be submitted by a notary as evidence, and are not included with the original (original deed) as ordered in Articles 66 and 66 A Notary Notary Office Law and Regulation of the Minister of Law and Human Rights number M .03. HT.03.10. In 2007, the notary is obliged to provide information, reasons and credible evidence to the investigator or judge regarding the missing or non-existent minuta (original deed) of the deed, so that the notary can provide other evidence such as a copy of the notary deed to the investigator. or a judge, if against the minuta (original deed) a notary has issued a copy of the deed. A copy of the notary deed and electronic document, both of which can be used as mutually reinforcing evidence.

In principle, a copy of the notary deed which is used as a photocopy, scan or print out in each trial must still be presented in the original because in Article 1889 paragraph (2) of the Civil Code, it has been determined that: "If the original deed exists, then the copies and summary. The summary is only trustworthy, only copies and summaries are by the original, which can always be ordered to show".

In Indonesia, the electronic proof system in the Transaction and Electronic Information Law is still exempted because letters and

10 Desy Rositawati, I Made Arya Utama, Desak Putu Dewi kasih, Penyimpanan Protokol Notaris Secara Elektronik Dalam Kaitan Cyber Notary, Acta Comitas Jurnal Hukum Kenotariatan, Vol 2 No 2, 2017, page.172-182. 
documents must be made in the form of notarial deeds or deeds drawn up by deed-making officials, also taking into account the provisions of Article 1868 of the Civil Code. In Article 1866 of the Civil Code, evidence consists of: 1) written evidence, 2) witness evidence, 3) suspicion, 4) confession, and 5) oath. Notary protocols that are stored electronically such as Print Out, scanning microfilm, hard disks or flash drives and other storage media, namely non-paper information storage devices that have a level of security that can guarantee the authenticity of documents transferred to them, as well as electronic documents that have been regulated as tools evidence recognized at court in the form of material law through the Company Documents Act and the transaction and electronic information law.

Apart from the transfer of documents in electronic form, the original manuscripts still have the power of authentic proof as long as they are made by the competent authority and the original manuscripts must be kept. And referring to Article 1888 of the Civil Code that the power of proof of written evidence is the original deed. In the process of proof in court if only electronic documents can be submitted by a notary as evidence, and are not included with the original (original deed) as ordered in Articles 66 and 66 A Notary Notary Office Law and Regulation of the Minister of Law and Human Rights number M .03. HT.03.10. In 2007, the notary is obliged to provide information, reasons and credible evidence to the investigator or judge regarding the missing or non-existent minuta (original deed) of the deed, so that the notary can provide other evidence such as a copy of the notary deed to the investigator. or a judge, if against the minuta (original deed) a notary has issued a copy of the deed. A copy of the notary deed and electronic document, both of which can be used as mutually reinforcing evidence.

In principle, a copy of the notary deed which is used as a photocopy, scan or print out in each trial must still be presented in the original because in Article 1889 paragraph (2) of the Civil Code, it has been determined that: "If the original deed exists, then the copies and summary The summary is only trustworthy, only copies Until now, there is no statutory regulation that discusses the extent to which electronic documents are similar or identical in the form of scans, printouts or print outs with the originals. In general, the acknowledgment of the validity of identical scans, printouts or printouts of electronic documents with the originals is if the parties are able and able to show the originals at court. As long as the original cannot be shown, the evidence cannot be used and must be accompanied by other evidence that can strengthen the evidence. Legal remedies that can be taken to realize notary protocol storage in electronic form, in the absence of laws and regulations that expressly regulate the electronic storage of notary protocols in the Notary Office Law, only in the Elucidation of Article 15 paragraph (3) which mentions the possibility of a notary public to certify transactions 
carried out electronically (cyber notary) as well as the restrictions provided by the Electronic Transaction Information of Law in Article 5 paragraph (4) that the electronic document does not meet the document authenticity requirements as stipulated in Article 1 point 7 of the Amendment Notary Notary Law and Article 1868 The Civil Code, makes the transfer of electronic notary protocol storage only to function as a back-up, not as a binding copy. Therefore it is necessary to revise the relevant legislation so that the electronic storage of deeds carried out by an electronic system whose operation is by the prevailing laws and regulations has the same evidentiary power as the original.

b. Legal Strength of Notary Protocol that is Stored Electronically in Evidence in the Field of Criminal Procedure Law

Minuta notary deed is part of an authentic deed, whose position is very important in terms of proof because the purpose of making and keeping the deed in the notary protocol section is a state archive used as evidence. The types of evidence in the Criminal Procedure Code (hereinafter referred to as KUHAP) that have been determined in Article 184 of the Criminal Procedure Code consist of Witness statements, expert opinions, letters, instructions, statements of the defendants. Without having to deviate from the existing legal provisions of evidence, the entrance for judges to accept various scriptless systems, but only by using electronic evidence can be done through the use of "multipurpose" evidence. as stated in Article 184 of the Criminal Procedure Code.

This electronic evidence can be used as evidence for a judge in making his decision in a criminal case. Evidence of guidance can be obtained through witness statements, letters, or statements of the accused. Judging from the five forms of evidence mentioned above, notary protocols that are stored electronically are included in the category of documentary evidence as regulated in Article 187 of the Criminal Procedure Code, so that the notary protocol which includes the minimum deed only acts as evidence if it relates to the contents of other evidence. Also, the judge can further examine the evidence so that if it is deemed adequate it can be used as evidence. This is by the Criminal Procedure Code system which wants judge's wisdom and conscientiousness based on their conscience in assessing the evidence of this directive, as stipulated in Article 188 paragraph (3) of the Criminal Procedure Code. Besides that, the evidence in the form of expert witnesses in interpreting the meaning of the proof and clarifying that the case is needed by the judge, so that it is hoped that the judge can decide the criminal case which he is judging more fairly and correctly.

c. Responsibility of Notary Public Against the Damage to the Notary Protocol that is Stored Electronically

Notaries as public officials who are given the authority by the state to carry out part of the state's duties, not solely for their own 
interests but also are responsible for being able to provide services and services for the interests of the parties related to civil law actions. The presence of technology in office activities makes it possible to manage archives through electronic media. Through this electronic media, it is hoped that the management of archives, including the storage of notary protocols, can be carried out better. The dangers of new information media (cyberspace and facilities such as libraries, archive storage places, databases, court files) include virus infections (which are very annoying), power cuts, breakthroughs, and destruction or destruction by careless or careless users. due to poor maintenance. ${ }^{11}$ Intentional loss and damage to notary protocols that are stored electronically by the notary is a violation. Potential violations of the law of notary protocols that are stored electronically by a notary public may cause harm to the parties. In the event that there is an opportunity for file manipulation (actions of adding, subtracting, deleting, changing without the knowledge of the parties) it can cause losses for the parties. In addition to causing losses, manipulation of these files also results in the absence of legal certainty.

According to Wirjono Projodikoro that accountability for a person's actions only means if that person commits an act that is not allowed and most of these acts are actions which in the Civil Code are called acts against the law. ${ }^{12}$ Article 1365 of the Civil Code regulates acts against the law, that "Every act against the law which therefore causes harm to others, obliges the person who because of his mistake caused the loss, to compensate for the loss".

Based on Article 1365 of the Civil Code, the elements formulated by J.H. Nieuwenhuis regarding acts against the law, namely:

1) The act which gives rise to losses is against the law because it contradicts the rights of others, morals, and the legal obligation of the perpetrator.

2) Losses arising as a result of said act.

3) The perpetrator is guilty.

4) The violated norms have "strekking" to type losses. ${ }^{13}$

Accountability must be carried out by a notary public in the event of something bad, such as committing fraud or deception originating from the notary itself. ${ }^{14}$ The Civil Code divides the problem

11 Tengku Erwinsyahbana, Melinda, Authorities and Responsibilities of the Substitute Notary after Implementation of Duties and Position Ends, Lentera Hukum Journal, Volume 5 Number 2, 2018, page 325

12 Elfa urdiana, Inter Criminal Liability Islamic Law Perspectives and Its Relevance on Criminal Law Updates Indonesia, A/ Mawarid Journal, Volume, XII, Number 1 February-August 2012, page 2

13 Edwar, Faisal A. Rani, Dahlan Ali, Notary Position As General Officers Are Reviewed From The Concept Of Equality Before The Law, Hukum dan Pembangunan Journal, Volume 49, Number 1, 2019, page 180.

14 Ida Bagus Paramaningrat Manuaba, I Wayan Parasa, Notary Concerning Principles In Creating Assets Authentic, Acta Comitas Journal, Volume 19, Nomor 1, April 2018, page.59. 
of accountability for acts against the law into 2 groups, namely direct responsibility and indirect responsibility. The statutory provisions of acts against the law aim to protect and provide compensation to the injured party. ${ }^{15}$

Regarding the notary's accountability for its protocols as stated in Article 65 of the Amendment of the Notary Office Law, that the notary is obliged and fully responsible for all of the protocols in his possession. making which is a notary protocol has ended at the same time as the term of office of the notary concerned. ${ }^{16}$

The legal responsibility of notaries for violations of notary protocols that are stored electronically is based on the Legal Liability Theory put forward by Kranenburg and Vegtig in the Fautes Personelles Theory that losses to third parties are borne by officials as individuals who because of their actions have caused losses. Based on this theory, the burden of responsibility is addressed to the notary as a person in carrying out his / her position in the event of a violation related to the notary's protocol stored electronically. Referring to the Legal Responsibility Theory put forward by Hans Kelsen, the notary is legally responsible for a certain act, meaning that the notary is responsible for a sanction in case of conflicting actions. Electronic storage of notary protocols is not regulated in Notary Office Law, so the resulting legal liability applies to the provisions of general law both civil, criminal, and administrative to the notary concerned.

\section{CONCLUSION}

The notary's electronic storage mechanism for notary protocols can be used to process media transfer from printed documents, audio, video into digital or scanning forms. The existence of electronic documents generated through this process can be opened when needed and a copy made for further use to represent the damaged or lost notary protocol. The legal power of proof of notary protocol that is stored electronically in evidence in the field of civil procedural law can only function as a back-up and not as a copy that has binding power, due to restrictions imposed by the Electronic Transaction Information Law in Article 5 paragraph (4) that the electronic document does not meet the document authenticity requirements as stipulated in Article 1 number 1 of the Amendment notary office law and Article 1868 of the Civil Code. The legal strength of the notary protocol that is stored electronically in evidence in the field of criminal procedure law acts as evidence when it relates to the contents of other evidence. Therefore it is necessary to revise the relevant legislation so that the storage of notary protocols carried out by an electronic system has the same evidentiary power as the original.

15 Novianti Wulandari Sitepu, Analysis Of Consumer Protection As Information Users Technology and Communiccations, Ius Civile Journal, Volume 4 Number 2, October 2020, page 117

16 Kunni Kaffah, Liability and Legal Protection for Notary in Civil Regarding the Deed He Made, Lex Renaissace Journal, Volume 1 Number 2, January 2017, page 147 


\section{BIBLIOGRAPHY}

\section{Books:}

Alimuddin Siregar, 2019, Pornography Law Regulations, Scopindo Media Pustaka, Surabaya;

Bambang Waluyo, 2002, Penelitian Hukum Dalam Praktek, Sinar Grafika, Jakarta;

Burhan Ashsofa, 2013, Metode Penelitian Hukum, Rineka Cipta, Jakarta;

R.Soegondo Notodisoeryo, 2012, Hukum Notariat di Indonesia, PT.Raja Grafindo, Fouth Publishing, Jakarta;

Titik Triwulan and Ismu Gunadi Widodo, 2011, State Administrative Law and Indonesian State Administrative Court Procedure, Kencana, Jakarta;

Y.Sri Pudyatmoko, 2009, Licensing: Problems and Efforts to Improve, Grasindo, Jakarta;

\section{Legislation:}

Law Number 30 of 2004 concerning the Position of Notary

\section{Journals:}

Abdul Muin, Notary's Responsibility To The Truth of Data In The Making of Islamic Banking Contract in Indonesia, Jurnal Pembaharuan Hukum, Volume V No. 1 April-Agustus 2018;

Cut Era Fitiyeni, Tanggung Jawab Notaris Terhadap Penyimpanan Minuta Akta Sebagai Bagian Dari Protokol Notaris, Kanun Jurnal IImu Hukum No. 58, th XIV Desember 2012;

Desy Rositawati, I Made Arya Utama, Desak Putu Dewi kasih, Penyimpanan Protokol Notaris Secara Elektronik Dalam Kaitan Cyber Notary, Acta Comitas Jurnal Hukum Kenotariatan, Vol 2 No 2, 2017;

Edwar, Faisal A. Rani, Dahlan Ali, Notary Position As General Officers Are Reviewed From The Concept Of Equality Before The Law, Hukum dan Pembangunan Journal, Volume 49, Number 1, 2019;

Elfa urdiana, Inter Criminal Liability Islamic Law Perspectives and Its Relevance on Criminal Law Updates Indonesia, A/ Mawarid Journal, Volume, XII, Number 1 February-August 2012;

Ida Bagus Paramaningrat Manuaba, I Wayan Parasa, Notary Concerning Principles In Creating Assets Authentic, Acta Comitas Journal, Volume 19, Nomor 1, April 2018;

Kunni Kaffah, Liability and Legal Protection for Notary in Civil Regarding the Deed He Made, Lex Renaissace Journal, Volume 1 Number 2, January 2017;

Mohamat Riza Kuswanto, Hari Purwadi, Urgensi Penyimpanan Protokol Notaris Dalam Bentuk Elektronik dan Kepastian Hukumnya di Indonesia, Jurnal Repertorium, Volume IV No. 2 Juli-Desember 2017; 
Novianti Wulandari Sitepu, Analysis Of Consumer Protection As Information Users Technology and Communiccations, Ius Civile Journal, Volume 4 Number 2, October 2020;

Tengku Erwinsyahbana, Melinda, Authorities and Responsibilities of the Substitute Notary after Implementation of Duties and Position Ends, Lentera Hukum Journal, Volume 5 Number 2, 2018; 